\title{
KEANEKARAGAMAN JENIS ANGGREK ALAM EPIFIT PADA BERBAGAI TUTUPAN TAJUK HUTAN DI DESA BALAI SEBUT KABUPATEN SANGGAU
}

\author{
(The Diversity of Epiphytic Natural Orchid Species in Various Forest Canopy Cover in the \\ Balai Sebut Village Sanggau District)
}

\author{
Dunatus Sudarso, Dwi Astiani, Hanna Artuti Ekamawanti \\ Fakultas Kehutanan Universitas Tanjungpura Jalan Daya Nasional Pontianak 78124 \\ Email: dunatuss@gmail.com
}

\begin{abstract}
Epiphytic orchids can be found living naturally in the tropical rainforest. Destruction or degradation of forest area in Balai Sebut District Sanggau Regency due to caused degradation of canopy cover. This condition may affect microclimate which than impacts at the presence of species, one of which is epiphytic orchids that grow naturally in the forest. This study used a survey method with purposive double plot sampling for 1 month (28 Mei-21 July 2019) in the field. Observation plots were made with a size of $20 \times 50 \mathrm{~m}$ with a total of 12 plots. The results showed that there where 32 types of epiphytic orchids with a total of 431 individuals. At closed forest canopy cover and had been accomplished (>70\%) can be 16 species of orchids with 220 individuals, at forest canopy (50-70\%) can be 25 species of orchids with 159 individuals, can be at open forest canopy cover (50\%) there were 10 species of orchids with 52 individuals. The dominant orchids species in the three canopy cover Flikingeria bicostata with Celogne peltastes.
\end{abstract}

Keywords: closed forest canopy, epiphytic orchids, medium and open forest canopy, species diversity.

\section{PENDAHULUAN}

Anggrek merupakan salah satu jenis tanaman hias yang memiliki bunga yang khas dengan mahkota yang indah dan warna yang menarik, hal ini membuat anggrek menjadi primadona di kalangan petani tanaman hias dan para pecinta bunga anggrek. Tumbuhan anggrek dapat dibagi menjadi dua manfaat yaitu secara ekologi dan ekonomi. Manfaat secara ekologi anggrek epifit mampu menjadi habitat untuk hewan seperti rayap dan semut. Secara ekonomi anggrek dimanfaatkan masyarakat untuk tanaman hias hal ini karena anggrek memiliki bentuk bunganya yang indah, warnawarna yang memikat dan dapat diperdagangkan (Anwar dkk. 1994). Anggrek tumbuh di daerah tropik dengan persebaran tempat tumbuh yang tidak seragam. Kehidupan jenis anggrek epifit dipengaruhi oleh intensitas cahaya matahari. Cahaya matahari berperan dalam memberikan energi bagi ekosistem untuk proses fotosintesis (Tirta dkk. 2010).

Anggrek alam memiliki bunga yang menarik dan tidak kalah indah dengan anggrek yang sudah disilangkan (Kartohadiprodjo. 2009). Hutan Desa Balai Sebut Kabupaten Sanggau memiliki kekayaan fauna dan flora yang beragam salah satunya jenis anggrek alam epifit. Kerusakan hutan yang diakibatkan oleh 
pembukaan lahan untuk ladang dan perkebunan oleh masyarakat mengakibatkan tajuk hutan terbuka. Perubahan pada tutupan tajuk hutan ini mempengaruhi iklim mikro pada lingkungan sekitar yang menimbulkan dampak bagi keanekaragaman jenis dan ekosistem yang hidup di hutan tersebut salah satunya anggrek epifit yang spesiesnya terancam punah (Sarwono 2002).

Kawasan hutan Desa Balai Sebut memiliki kekhasan tumbuh-tumbuhan, METODE PENELITIAN

Penelitian dilaksanakan di kawasan hutan lindung Desa Balai Sebut Kabupaten Sanggau. Kegiatan penelitian dilakukan di lapangan mulai tanggal 28 Mei - 21 Juni 2019 dan dilanjutkan dengan pengolahan data. Desa Balai Sebut umumnya memiliki topografi berbukit dan bergelombang, sedangkan jenis tanah sebagian besar podsolit merah kuning (PMK) dan selebihnya tanah alluvial dan latosol. Bulan basah berkisar dari Oktober - April dan bulan kering berkisar dari bulan Mei - Oktober, sedangkan letak Desa Balai Sebut adalah sebelah Timur berbatasan dengan Desa Semirau, sebelah Barat berbatasan dengan Desa Jangkang, sebelah Utara berbatasan dengan Desa Sape, dan sebelah Selatan berbatasan dengan Desa Ketori.

Penelitian ini menggunakan metode survei dengan pengambilan contoh petak ganda secara purposive. Petak pengamatan untuk jenis-jenis anggrek dibuat dengan ukuran 20 x $50 \mathrm{~m}$. Dasar peletakan plot pengamatan dilakukan secara purposive pada tutupan tajuk tertutup (>70\%), salah satunya anggrek epifit yang ditemukan pada berbagai tutupan tajuk hutan. Sampai saat ini pengaruh perbedaan keanekaragaman jenis anggrek epifit pada ketiga tutupan tajuk hutan belum banyak diketahui. Tujuan pen elitian ini adalah mendeskripsikan keaneka ragaman jenis anggrek epifit yang ada di kawasan hutan Desa Balai Sebut pada ketiga

tutupan tajuk hutan, yaitu tajuk tertutup, se dang dan terbuka.

tutupan tajuk sedang (50-70\%) dan tutupan tajuk terbuka (50\%). Peletakan plot di setiap tutupan dibuat 4 plot dengan pertimbangan melihat komposisi jenis anggrek setelah dilakukan orientasi lapangan berdasarkan pada ketiga tutupan tajuk hutan. Jumlah keseluruhan plot pengamatan yang dibuat pada ketiga tutupan sebanyak 12 plot dengan total luasan petak penelitian keseluruhan 1,2 ha. Identifikasi jenis anggrek mengunakan buku Anggrek Spesies Kalimantan Barat Volume 1 karangan (Chairani dkk 2005), Orchid of Indonesia karya (Frenkie 2010). Pengambilan sampel mulai dari data jenisjenis anggrek, jumlah jenis anggrek, jumlah individu dari masing-masing jenis, tutupan tajuk, data pohon inang, data tempat tumbuh anggrek (pohon).

Analisis kuantitatif dilakukan dengan cara menghitung indeks keanekaragaman jenis, frekuensi, dominansi, Indeks Nilai Penting, indeks kekayaan jenis, indeks kemerataan jenis dan indek kesamaan jenis

HASIL DAN PEMBAHASAN Keanekaragaman Jenis Anggrek Epifit 
Berdasarkan data yang dikumpulkan di lapangan diketahui bahwa jenis-jenis anggrek alam yang terdapat pada kawasan hutan di Desa Balai Sebut ditemukan komposisi jenis anggrek yang beragam. Hal ini dapat dilihat berdasarkan pada masing-masing petak pengamatan ditiga tutupan tajuk hutan yang berbeda. Tutupan tajuk hutan tertutup (ditemukan 16 jenis anggrek dengan 220 individu) dari 16 jenis anggrek tersebut, (3 jenis) diantaranya tidak ditemukan hidup pada tutupan tajuk hutan sedang dan tajuk hutan terbuka yaitu jenis Bulbophyllum gracilimum, Eria lelophylla dan Thecopus sekunda. Ketiga jenis anggrek tersebut hanya ditemukan hidup pada tutupan tajuk hutan tertutup, hal ini didukung ketiga jenis anggrek tersebut hanya ditemukan hidup ditempat yang penyinaran cahaya matahari sedikit menembus lantai hutan. Tutupan tajuk hutan berkaitan erat dengan penguasaan tumbuhan anggrek untuk dapat tumbuh yang dipengaruhi oleh besarnya energi yang diperoleh dari cahaya matahari, kelembapan dan hara mineral yang dihasilkan (Komara 2008).

Pada tutupan tajuk hutan sedang (ditemukan 25 jenis anggrek dengan 159 individu), dari 25 jenis anggrek yang ditemukan ada (12 jenis anggrek) tidak ditemukan hidup pada tutupan tajuk hutan tertutup dan tajuk hutan terbuka (tabel 1). Jenis-jenis anggrek tersebut ditemukan hanya hidup pada pohon yang memiliki permukaan kulit yang kasar, pacah-pecah dan tebal seperti kayu bintangur, keruing, ubah, laban dan jenis meranti. Kondisi tersebut membuat 12 jenis anggrek tersebut dapat hidup dengan baik pada tutupan tajuk hutan sedang (Puspitaningtyas 2010).

Pada tutupan tajuk terbuka (ditemukan 10 jenis anggrek dengan 52 individu) dari 10 jenis anggrek tersebut 4 jenis diantaranya tidak ditemukan hidup pada tutupan tajuk hutan tertutup dan tajuk hutan sedang yaitu jenis Bulbophyllum planibulbe, Dendrobium carbro, Dendrobium pinifolium dan Dendrobium prostratum. Jenis-jenis anggrek tersebut ditemukan hidup pada batang pohon yang sudah mati yang memiliki permukaan kulit kayu kasar, tebal dan pada tempat yang terbuka dengan penyinaran matahari langsung (Febriliani dkk 2013).

Hasil penelitian dari 12 petak pengamatan jenis yang paling dominan dari 32 jenis tersebut adalah jenis anggrek Apendicula sp., Bulbophyllum pileatum, Bulbophyllum limbatum, Ceologyne peltastes, Dendrobium microglaphyss dan Flikingeria bicostata. Jenis-jenis ini ditemukan hidup pada ketiga tutupan tajuk hutan yang diamati dengan (INP lebih besar dari 10\%). Berdasarkan hasil tersebut dapat disimpulkan bahwa 6 jenis anggrek alam epifit tersebut mampu hidup optimum dan menyebar baik di tiga tutupan tajuk hutan di Desa Balai Sebut. Anggrek umumnya membutuhkan cahaya matahari dalam jumlah yang tidak sama. Anggrek epifit membutuhkan intensitas cahaya matahari rendah, yakni sekitar 25$50 \%$ dan anggrek terristrik membutuhkan cahaya dalam jumlah yang tinggi, yakni 60-75\% (Iswanto 2002). Tingkat lapisan hutan biasanya mempunyai iklim yang berbeda-beda, jika intensitas cahaya matahari rendah, proses fotosintesis yang 
berjalan juga rendah. Dampaknya pertumbuhan tanaman menjadi terhambat, jaringan tanaman menjadi lunak dan proses pembentukan bunga menjadi terhambat.

Adapun jenis anggrek yang mendominasi di tiga tutupan tajuk hutan di Desa Balai Sebut yaitu anggrek jenis anggrek Flikingeria bicostata dengan nilai INP sebesar 33,57\%. Flikingeria bicostata memiliki kemampuan untuk memanfaatkan cahaya matahari dan penyesuaian lingkungan dengan optimal. Kehidupan anggrek epifit dipengaruhi oleh intensitas matahari yang memberikan energi bagi ekosistem untuk berfotosintesis (Tirta dkk. 2010).

Berdasarkan hasil pengamatan dilapangan terdapat 32 jenis anggrek dengan jumlah keseluruhan individu 431 individu, dapat dilihat pada tabel 1:

Tabel 1. Jumlah jenis-jenis anggrek yang ditemukan pada 3 tutupan tajuk hutan (amount of orchids found in three forest canopy cover)

\begin{tabular}{|c|c|c|c|c|c|c|c|c|}
\hline \multirow[b]{2}{*}{ No } & \multirow[b]{2}{*}{ Jenis } & \multicolumn{5}{|c|}{ Tutupan } & \multirow[b]{2}{*}{ INP } & \multirow[b]{2}{*}{ Total } \\
\hline & & Tertutup & INP & Sedang & INP & Terbuka & & \\
\hline 1 & Agrosthophyllum stipulatum & - & - & 3 & 6,887 & - & - & 3 \\
\hline 2 & Apendicula sp. & 24 & 22,1 & 4 & 5,016 & - & - & 28 \\
\hline 3 & Bulbophyllum bakoense & 6 & 6,43 & 1 & 3,129 & - & - & 7 \\
\hline 4 & B. beccarii & 11 & 8,7 & 7 & 9,403 & - & - & 18 \\
\hline 5 & B. cuspidipetalum & - & - & 3 & 4,387 & - & - & 3 \\
\hline 6 & B. gracilimum & 5 & 5,97 & - & - & - & - & 5 \\
\hline 7 & B. limbatum & 8 & 11,05 & 17 & 18,19 & 2 & 10,989 & 27 \\
\hline 8 & B. longiflorum & - & - & 2 & 3,758 & - & - & 2 \\
\hline 9 & B. lyriforme & 26 & 15,52 & 6 & 8,774 & - & - & 32 \\
\hline 10 & B. otochillum & - & - & 7 & 9,403 & - & - & 7 \\
\hline 11 & B. pileatum & 16 & 14,68 & 5 & 5,645 & - & - & 21 \\
\hline 12 & B. planibulbe & - & - & - & - & 1 & 9,065 & 1 \\
\hline 13 & B. purpurascens & - & - & 3 & 4,387 & - & - & 3 \\
\hline 14 & B.riticulatum & - & - & 5 & 5,645 & - & - & 5 \\
\hline 15 & B. rubiferum & - & - & 2 & 3,758 & - & - & 2 \\
\hline 16 & Bulbophyllum sp. & 3 & 5,06 & 7 & 6,903 & - & - & 10 \\
\hline 17 & B. triflorum & 15 & 10,52 & 3 & 4,387 & - & - & 18 \\
\hline 18 & B. vaginatum & - & - & 3 & 4,387 & - & - & 3 \\
\hline 19 & B. acuminatum & - & - & 16 & 20,06 & - & - & 16 \\
\hline 20 & C. peltastes & 3 & 8,77 & 16 & 17,56 & 16 & 45,055 & 35 \\
\hline 21 & Coelogyne sp. & 2 & 4,61 & 3 & 4,387 & 8 & 22,527 & 13 \\
\hline 22 & Dendrobium carbro & - & - & - & - & 4 & 21,978 & 4 \\
\hline 23 & D. leonis & 2 & 4,61 & 7 & 11,9 & 4 & 21,978 & 13 \\
\hline 24 & D. microglaphyss & 19 & 23,45 & 8 & 7,531 & 5 & 16,785 & 32 \\
\hline 25 & D. kenepaiense & - & - & 1 & 3,129 & - & - & 1 \\
\hline 26 & D. pinifolium & - & - & - & - & 3 & 12,912 & 3 \\
\hline 27 & D. prostratum & - & - & - & - & 1 & 9,065 & 1 \\
\hline 28 & Eria lelophylla & 4 & 5,52 & - & - & - & - & 4 \\
\hline 29 & Eria sp. & - & - & 3 & 4,387 & - & - & 3 \\
\hline 30 & Flikingeria bicostata & 74 & 48,45 & 24 & 22,59 & 8 & 29,67 & 106 \\
\hline 31 & Thecopus sekunda & 2 & 4,61 & - & - & - & - & 2 \\
\hline \multirow[t]{2}{*}{32} & Trixspermum sp. & - & - & 3 & 4,387 & - & - & 3 \\
\hline & Total & 220 & 200 & 159 & 200 & 52 & 200 & 431 \\
\hline
\end{tabular}


Tutupan tajuk hutan tertutup jumlah jenis anggrek yang ditemukan 16 jenis dengan jenis anggrek yang dominan ditemukan yaitu jenis Apendicula sp. dengan INP 22,1, Dendrobium microglaphyss INP 23,45 dan Flikingeria bicostata 48,45. Tiga jenis anggrek tersebut memiliki jumlah kehadiran individu lebih besar dibandingkan dengan jenis yang lain dengan nilai INP lebih besar dari 20\%. Pada tutupan tajuk hutan sedang jumlah anggrek yang ditemukan 25 jenis dengan jenis yang dominan ditemukan yaitu Flikingeria bicostata. Jenis anggrek tersebut jumlah kehadiran individu yang ditemukan lebih besar dari jenis anggrek yang lain dengan nilai INP lebih besar dari $20 \%$. Pada tutupan tajuk hutan terbuka jumlah jenis anggrek yang ditemukan 10 jenis dengan jenis yang dominan ditemukan yaitu jenis Coelogyne peltastes. Jenis anggrek tersebut jumlah kehadiran individu yang ditemukan lebih besar dari jenis anggrek yang lain dengan nilai INP lebih besar dari $20 \%$. Perbedaan jumlah jenis anggrek dan INP yang ditemukan pada ketiga jenis tutupan tajuk hutan menandakan perbedaan tutupan berpengaruh terhadap kehidupan jenis anggrek. Cahaya berpengaruh besar terhadap kehidupan anggrek, baik secara langsung maupun tidak langsung. Pengaruh langsung yaitu pada proses fotosintesis sedangkan secara tidak langsung yaitu berpengaruh terhadap pertumbuhannya dan perkecambahan (Febriliani dkk 2013).

\section{Asosiasi Pohon Tempat Tumbuh Anggrek Pada Tajuk Tertutup}

Berdasarkan hasil pengamatan dilapangan jenis-jenis anggrek yang berasosiasi dengan pohon pada tutupan tajuk tertutup dapat dilihat pada tabel 2:

Tabel 2. Data asosiasi pohon tempat tumbuh anggrek pada tajuk tertutup (data on the association of trees in which orchid grow in a closed forest canopy)

\begin{tabular}{|c|c|c|}
\hline No & Jenis & Pohon Tempat Tumbuh \\
\hline 1 & Apendicula sp. & keruing (Dipterocarpus obligofolius), ubah (Eugenia sp.) \\
\hline 2 & Bulbophyllum bakoense & asam (Mangifera sp.), medang (Litsea angulata) \\
\hline 3 & B. beccarii & $\begin{array}{l}\text { keruing (Dipterocarpus obligofolius), meranti (Shorea sp.), terap } \\
\text { (Artocarpus elasticus) }\end{array}$ \\
\hline 4 & B. gracilimum & $\begin{array}{l}\text { laban (Vitex pubescens), asam (Mangifera sp.), keruing } \\
\text { (Dipterocarpus obligofolius) }\end{array}$ \\
\hline 5 & B. limbatum & tengkawang (Shorea pinanga), medang (Litsea angulata) \\
\hline 6 & B. lyriforme & keruing (Dipterocarpus obligofolius), meranti (Shorea sp.) \\
\hline 7 & B. pileatum & meranti (Shorea sp.), terap (Artocarpus elasticus), \\
\hline 8 & Bulbophyllum sp. & medang (Litsea angulata) dan tengkawang (Shorea pinanga) \\
\hline 9 & B. triflorum & laban (Vitex pubescens), medang (Litsea angulata) \\
\hline 10 & Coelogyne peltastes & ubah (Eugenia sp.), asam (Mangifera sp.) \\
\hline 11 & Coelogyne sp. & laban (Vitex pubescens), asam (Mangifera sp.) \\
\hline 12 & Dendrobium leonis & ubah (Eugenia sp.), tengkawang (Shorea pinanga) \\
\hline 13 & D. microglaphyss & $\begin{array}{l}\text { keruing (Dipterocarpus obligofolius), meranti (Shorea sp.), terap } \\
\text { (Artocarpus elasticus) }\end{array}$ \\
\hline 14 & Eria lelophylla & asam (Mangifera sp.), keruing (Dipterocarpus obligofolius) \\
\hline 15 & Flikingeria bicostata & $\begin{array}{l}\text { tengkawang (Shorea pinanga), meranti (Shorea sp.), Ubah (Eugenia } \\
\text { sp.) }\end{array}$ \\
\hline 16 & Thecopus sekunda & keruing (Dipterocarpus obligofolius), meranti (Shorea sp.) \\
\hline
\end{tabular}


Pada Tabel 2 anggrek $D$. microglaphyss berasosiasi dengan pohon jenis keruing (Dipterocarpus obligofolius), meranti (Shorea sp.), terap (Artocarpus elasticus) dan jenis anggrek Flikingeria bicostata berasosiasi dengan tengkawang (Shorea pinanga), terap (Artocarpus elasticus), meranti (Shorea sp.), ubah (Eugenia sp.). Jenis-jenis pohon tersebut memiliki ciri-ciri permukaan kulit yang kasar, tebal dan retakretak serta dengan kondisi tajuk yang relatif baik berbentuk payung, bentuk percabangan normal dan tidak terlalu rimbun, cahaya matahari masih bisa menembus lantai hutan sehingga dimanfaatkan anggrek untuk tumbuh dan berkembang. Kondisi ini membuat jenis anggrek Apendicula sp., D. microglaphyss dan Flikingeria bicostata berkembang dengan baik pada tutupan tajuk hutan tertutup (Sujalu dan Pulihasih 2010).

\section{Asosiasi Pohon Tempat Tumbuh} Anggrek Pada Tutupan Tajuk Sedang

Berdasarkan hasil pengamatan dilapangan jenis-jenis anggrek yang berasosiasi dengan pohon pada tutupan tajuk sedang dapat dilihat pada tabel 3:

Tabel 3. Data asosiasi pohon tempat tumbuh anggrek pada tajuk sedang (data on the association of trees in which orchid grow in a medium forest canopy)

\begin{tabular}{|c|c|c|}
\hline No & Jenis & Pohon Tempat Tumbuh \\
\hline 1 & Agrosthophyllum stipulatum & bintangur (Callophyllum inophyllum), ubah (Eugenia sp.) \\
\hline 2 & Apendicula sp. & keruing (Dipterocarpus obligofolius), ubah (Eugenia sp.) \\
\hline 3 & Bulbophyllum acuminatum & keruing (Dipterocarpus obligofolius), meranti (Shorea sp.) \\
\hline 4 & B. bakoense & asam (Mangifera sp.), medang (Litsea angulata) \\
\hline 5 & B. beccari & $\begin{array}{l}\text { keruing (Dipterocarpus obligofolius), meranti (Shorea sp.), } \\
\text { terap (Artocarpus elasticus) }\end{array}$ \\
\hline 6 & B. cuspidipetalum & $\begin{array}{l}\text { laban (Vitex pubescens), asam (Mangifera sp.), keruing } \\
\text { (Dipterocarpus obligofolius) }\end{array}$ \\
\hline 7 & B. limbatum & tengkawang (Shorea pinanga), medang (Litsea angulata) \\
\hline 8 & B. longifolium & meranti (Shorea sp.), terap (Artocarpus elasticus), \\
\hline 9 & B. lyriforme & keruing (Dipterocarpus obligofolius), meranti (Shorea sp.) \\
\hline 10 & B. otochillum & asam (Mangifera sp.), terap (Artocarpus elasticus) \\
\hline 11 & B. pileatum & meranti (Shorea sp.), terap (Artocarpus elasticus) \\
\hline 12 & B. purpurascens & laban (Vitex pubescens), ubah (Eugenia sp.) \\
\hline 13 & B. riticulatum & $\begin{array}{l}\text { terap (Artocarpus elasticus), bintangur (Callophyllum } \\
\text { inophyllum), medang (Litsea angulata) }\end{array}$ \\
\hline 14 & B.rubiferum & laban (Vitex pubescens), asam (Mangifera sp.) \\
\hline 15 & Bulbophyllum sp. & medang (Litsea angulata) dan tengkawang (Shorea pinanga) \\
\hline 16 & B. triflorum & $\begin{array}{l}\text { laban (Vitex pubescens), medang (Litsea angulata), asam } \\
\text { (Mangifera sp.) }\end{array}$ \\
\hline 17 & B.vaginatum & $\begin{array}{l}\text { asam (Mangifera sp.), medang (Litsea angulata) dan } \\
\text { tengkawang (Shorea pinanga) }\end{array}$ \\
\hline 18 & Coelogyne peltastes & ubah (Eugenia sp.), asam (Mangifera sp.) \\
\hline 19 & Coelogyne sp. & laban (Vitex pubescens), bintangur (Callophyllum inophyllum) \\
\hline 20 & Dendrobium leonis & ubah (Eugenia sp.), tengkawang (Shorea pinanga) \\
\hline 21 & D. Microglaphyss & $\begin{array}{l}\text { keruing (Dipterocarpus obligofolius), meranti (Shorea sp.), } \\
\text { terap (Artocarpus elasticus) }\end{array}$ \\
\hline 22 & D. kenepaiense & laban (Vitex pubescens) \\
\hline 23 & Eria sp. & $\begin{array}{l}\text { keruing (Dipterocarpus obligofolius), meranti (Shorea sp.), } \\
\text { terap (Artocarpus elasticus) }\end{array}$ \\
\hline 24 & Flikingeria bicostata & $\begin{array}{l}\text { tengkawang (Shorea pinanga), terap (Artocarpus elasticus), } \\
\text { meranti (Shorea sp.), ubah (Eugenia sp.) }\end{array}$ \\
\hline 25 & Trixspermum sp. & medang (Litsea angulata) dan tengkawang (Shorea pinanga) \\
\hline
\end{tabular}


Jenis-jenis anggrek pada tutupan tajuk hutan sedang yang penyebarannya merata dan kehadirannya selalu ada ditemukan disetiap plot pengamatan yaitu jenis anggrek Bulbophyllum acuminatum. Anggrek Bulbophyllum acuminatum rata-rata ditemukan pada batang pohon yang hidup dan berasosiasi dengan pohon keruing (Dipterocarpus obligofolius), meranti (Shorea sp.). Anggrek jenis B. acuminatum penyebarannya merata pada setiap plot pengamatan, hal ini didukung dengan jenis pohon yang menjadi tempat tumbuh anggrek tersebut hampir merata penyebaranya pada setiap plot sehingga anggrek $B$. acuminatum dapat tumbuh dengan baik pada tutupan tajuk hutan sedang. Jenis pohon keruing
(Dipterocarpus obligofolius), meranti (Shorea sp.) merupakan pohon yang memiliki ciri-ciri kulit pada batang yang kasar, pecah-pecah sehingga memudahkan tumbuhan anggrek jenis B. acuminatum untuk tumbuh.

Pohon yang memiliki permukaan kulit kasar dan pecah-pecah memungkinkan serasah dan air tersangkut lebih baik dibandingkan dengan kulit pohon yang halus (Puspitaningtyas 2010).

\section{Asosiasi Pohon Tempat Tumbuh Anggrek Pada Tutupan Tajuk Sedang}

Berdasarkan hasil pengamatan dilapangan jenis-jenis anggrek yang berasosiasi dengan pohon pada tutupan tajuk ternuka dapat dilihat pada tabel 4 :

Tabel 4. Data asosiasi pohon tempat tumbuh anggrek pada tutupan tajuk terbuka (the association of trees in which orchid grow at oven canopy cover)

\begin{tabular}{|c|c|c|}
\hline No & Jenis & Pohon Tempat Tumbuh \\
\hline 1 & $\begin{array}{l}\text { Bulbophyllum } \\
\text { limbatum }\end{array}$ & tengkawang (Shorea pinanga), medang (Litsea angulata) \\
\hline 2 & B. planibulbe & $\begin{array}{l}\text { ubah (Eugenia sp.), meranti (Shorea sp.), keruing (Dipterocarpus } \\
\text { obligofolius) }\end{array}$ \\
\hline 3 & $\begin{array}{l}\text { Coelogyne } \\
\text { peltastes }\end{array}$ & ubah (Eugenia sp.), asam (Mangifera sp.) \\
\hline 4 & Coelogyne sp. & laban (Vitex pubescens), bintangur (Callophyllum inophyllum) \\
\hline 5 & $\begin{array}{l}\text { Dendrobium } \\
\text { carbro }\end{array}$ & meranti (Shorea sp.), bintangur (Callophyllum inophyllum) \\
\hline 6 & D. leonis & ubah (Eugenia sp.), tengkawang (Shorea pinanga) \\
\hline 7 & D. microglaphyss & $\begin{array}{l}\text { keruing (Dipterocarpus obligofolius), meranti (Shorea sp.), terap (Artocarpus } \\
\text { elasticus) }\end{array}$ \\
\hline 8 & D. pinifolium & meranti (Shorea sp.), ubah (Eugenia sp.) \\
\hline 9 & D. prostratum & tengkawang (Shorea pinanga), meranti (Shorea sp.) \\
\hline 10 & $\begin{array}{l}\text { Flikingeria } \\
\text { bicostata }\end{array}$ & $\begin{array}{l}\text { keruing (Dipterocarpus obligofolius), tengkawang (Shorea pinanga), meranti } \\
\text { (Shorea sp.) }\end{array}$ \\
\hline
\end{tabular}

Persentase (\%) ditemukannya jenisjenis anggrek pada tutupan tajuk hutan terbuka dari 4 plot yang telah diamati jenis-jenis anggrek yang selalu ada ditemukan disetiap plot pengamatan yaitu jenis anggrek Coelogyne peltastes. Jenis anggrek ini rata-rata ditemukan pada batang dan cabang pohon yang masih hidup dan berasosiasi dengan pohon jenis ubah (Eugenia sp.), asam 
(Mangifera sp.). Jenis-jenis pohon tersebut memiliki ciri-ciri permukaan kulit yang kasar dan tebal. Kayu yang memiliki permukaan kulit kasar cenderung disukai oleh anggrek untuk tempat tumbuh.

\section{Indeks Dominansi (C)}

Indeks dominansi jenis anggrek epifit pada setiap tutupan tajuk hutan tertutup, hutan sedang dan terbuka dikategorikan rendah. Anggrek yang ditemukan pada tajuk hutan tertutup mengandung sedikit jenis dimana

Keanekaragaman jenis (Species diversity) adalah suatu karakteristik tingkat komunitas berdasarkan biologisnya, yang dapat menyatakan struktur komunitas (Soegianto 1994), sedangkan diversity indeks adalah nilai yang dapat menunjukkan tinggi rendahnya keanekaragaman populasi

Tabel 9. Daftar indeks dominansi (C), kekayaan jenis (D), keanekaragaman jenis (H) dan kelimpahan jenis (e) pada tiga tutupan tajuk hutan (list of indek dominance, species diversity and abundance of species in three forest canopy cover).

\begin{tabular}{llllll}
\hline No & Tutupan Tajuk & C & D & H' & E \\
\hline 1 & Hutan tertutup & 0,153 & 6,404 & 0,918 & 0,999 \\
2 & Hutan sedang & 0,0062 & 10,902 & 1,224 & 1,403 \\
3 & Hutan terbuka & 0,0192 & 5,245 & 0,869 & 1,14 \\
\hline
\end{tabular}

Berdasarkan nilai (H') pada Tabel 9 menunjukkan bahwa diantara ketiga tutupan tajuk tersebut, indeks keanekaragaman jenis yang menonjol yaitu pada tutupan tajuk hutan sedang dan dikategorikan tingkat keanekaragaman jenisnya sedang, pada tutupan tajuk hutan tertutup dan terbuka tingkat keanekaragaman jenisnya rendah (Shannon dan Wiener 1949). Jenis-jenis anggrek yang ditemukan pada tutupan tajuk hutan sedang semakin bertambah bila dibandingkan ditemukan 16 jenis tetapi jumlah individu yang ditemukan lebih besar yaitu 220 individu, dengan jenis yang sedikit maka penguasaan terhadap tempat tumbuh semakin tinggi dengan demikian pola pemusatan jenis-jenis yang dominan akan tersebar merata. Jenis-jenis yang memiliki nilai frekuensi

relatif tinggi memiliki kerapatan yang ti nggi dan cenderung menempati area yan g luas (Tanjung dkk. 2010).

\section{Keanekaragaman Jenis (H')}

dari jenis-jenis yang berbeda didalam komunitas. Berdasarkan hasil pengamatan di lapangan daftar indek dominansi (C), kekayaan jenis (D), keanekaragaman jenis $(\mathrm{H})$ dan kelimpahan jenis (e) dapat dilihat pada tabel 9:

dengan tutupan tajuk tertutup dan tajuk terbuka. Hal ini menunjukan bahwa pada tutupan tajuk sedang cocok untuk anggrek tumbuh dan berkembang sehingga jenis anggrek ditemukan lebih beragam jika dibandingkan dengan kedua tutupan tajuk hutan tertutup dan terbuka. keanekaragaman anggrek epifit di berbagai jenis pohon inang dipengaruhi oleh kondisi iklim mikro tegakan hutan, sesuai dengan pendapat yang dikemukakan oleh (Febriliani dkk. 2013). 


\section{Indeks Kekayan Jenis (D)}

Indeks kekayaan jenis tertinggi terjadi pada tutupan tajuk hutan sedang. Indeks kekayaan jenis ini lebih tinggi dibandingkan dengan 2 jenis tutupan tajuk lainnya. Hal ini menunjukan bahwa pada tutupan tajuk sedang anggrek sangat cocok tumbuh pada kondisi tersebut sehingga kekayaan jenis pada tutupan tersebut paling tinggi. Pada Tajuk hutan sedang tumbuhan anggrek dapat tumbuh dan menyesuaikan diri dengan baik dibandingkan dengan tutupan tajuk hutan tertutup dan terbuka. Tutupan pada tajuk hutan berkaitan erat dengan penguasaan tumbuhan anggrek untuk bisa tumbuh yang dipengaruhi oleh besarnya energi yang diperoleh dari cahaya matahari, kelembaban dan hara mineral yang dihasilkan (Komara, 2008).

\section{Indeks Kelimpahan Jenis (e)}

Indeks kelimpahan jenis pada ketiga tutupan tajuk hutan tersebut dapat disimpulkan kelimpahan jenisnya melimpah. Hal ini dapat dilihat pada nilai indeks ketiga tutupan tajuk yang rata-rata hampir 1 (Odum 1993). Berdasarkan hasil pengamatan dilapangan tabel indeks kesamaan jenis berdasarkan perbandingan jumlah jenis antar tutupan tajuk hutan dapat dilihat pada tabel 10:

Tabel 10. Daftar indeks kesamaan jenis berdasarkan perbandingan jumlah jenis antar tutupan tajuk hutan (a list of species similarity indeks based on a comparison of the number forest canopy cover)

\begin{tabular}{lcccc}
\hline No & Tutupan Tajuk & $\begin{array}{c}\text { Jenis Yang } \\
\text { Sama }(\mathbf{C})\end{array}$ & $\begin{array}{c}\text { Jumlah Jenis } \\
(\mathbf{A + B})\end{array}$ & $\begin{array}{c}\text { Indek kesamaan } \\
(\mathbf{2 C} / \mathbf{A}+\mathbf{B}) \mathbf{x} \mathbf{1 0 0 \%}\end{array}$ \\
\hline 1 & Tajuk tertutup - Tajuk sedang & 12 & 41 & 58,536 \\
2 & Tajuk tertutup - Tajuk terbuka & 6 & 26 & 46,153 \\
3 & Tajuk sedang - Tajuk terbuka & 6 & 35 & 34,285 \\
\hline
\end{tabular}

Total

Perbandingan indeks of similarity (IS) antara tutupan tajuk hutan tertutup dengan tajuk sedang memiliki nilai kesamaan jenis yang berbeda dan Perbandingan antara ketiga tutupan tajuk yaitu tajuk tertutup -

Keberadaan anggrek pada suatu pohon dan saling berasosiasi dengan tumbuhan lain memang erat hubungannya untuk menjaga kelangsungan hidup anggrek itu sendiri. Sebagai mana yang kita tahu bahwa pohon inang sangat penting khususnya bagi anggrek epifit dalam rangka penerimaan unsur hara serta oksigen dan unsur-unsur lain yang diserap dari udara. Berdasarkan hasil pengamatan pohon inang yang menjadi tempat tumbuh tajuk terbuka dan tajuk sedang - tajuk terbuka memiliki tingkat kesamaan komposisi jenis yang berbeda (Odum 1993).

\section{Asosiasi}

anggrek, diperoleh jenis-jenis pohon diantaranya seperti: ubah (Eugenia sp.), laban (Vitex pubescens), asam (Mangifera sp.), keruing (Dipterocarfus obligofolius), meranti (Shorea sp.), terap (Artocarpus elasticus), bintangur (Callophyllum inophyllum), medang (Litsea angulata) dan tengkawang (Shorea pinanga).

Pertumbuhan dan kelimpahan jenis epifit dipengaruhi oleh beberapa faktor seperti; keadaan pohon yang meliputi 
susunan tajuk, permukaan kulit kayu, bentuk percabangan hal ini sangat mempengaruhi perkembangan tumbuhan epifit (Pratomihardjo dan Kartawinata 1984). Permukaan kulit pohon yang kasar juga sangat menguntungkan anggrek dalam hal mensuplai air dan hara mineral di lingkungan. Selanjutnya pohon yang permukaan kulit kasar dapat menyerap air lebih banyak pada waktu hujan dibandingkan dengan pohon yang memiliki permukaan kulit yang halus (Puspitaningtyas 2010). Hal ini sesuai dengan pendapat Ewusie (1990) bahwa jenis anggrek epifit lebih menyukai kulit kayu yang tebal dan kasar sebagai tempat untuk hidup serta pohon-pohon yang sudah mati.

Berdasarkan hasil penelitian ditemukan beberapa jenis anggrek ditemukan hidup menempel pada batang pohon yang sudah mati seperti anggrek jenis Dendrobium kenepaiense, D. carbro, $D$. pinifolium, $D$. leonis dan ada juga jenis anggrek epifit yang ditemukan hidup menempel pada vegetasi lain yang permukaan batangnya ditutupi oleh lumut seperti jenis anggrek Bulbophyllum sp., Bulbophyllum medusae. Hal ini sesuai dengan pendapat yang dikemukakan Sutiyoso dan Sarwono (2005) bahwa sebagian besar anggrek yang ditemukan di hutan tropis adalah jenis yang biasanya ditemukan pada batang, cabang-cabang pohon, dahan dan batang pohon yang sudah mati pada daerah yang memiliki kelembaban dan curah hujan tinggi.

Jenis-jenis anggrek yang ditemukan pada tutupan tajuk hutan di 12 petak pengamatan hutan Desa Balai Sebut

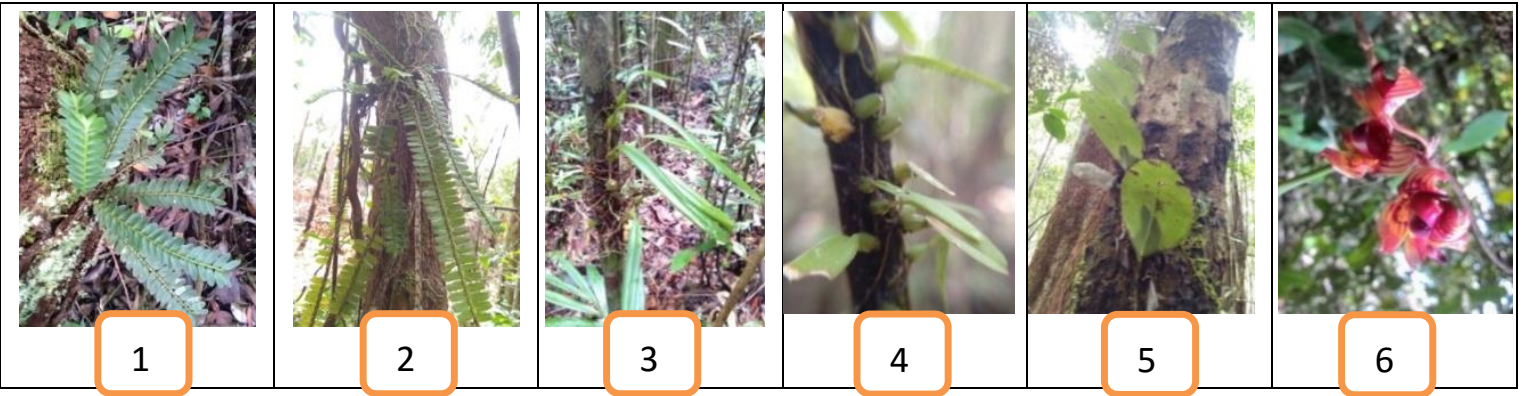

Apendicula sp. (1), (2) Agrosthophyllum stipulatum, (3) Bulbophyllum acuminatum (Ridl), (4)

Bulbophyllum bakoense, (5) Bulbophyllum beccarii, dan (6) Bulbophyllum cuspidipetalum

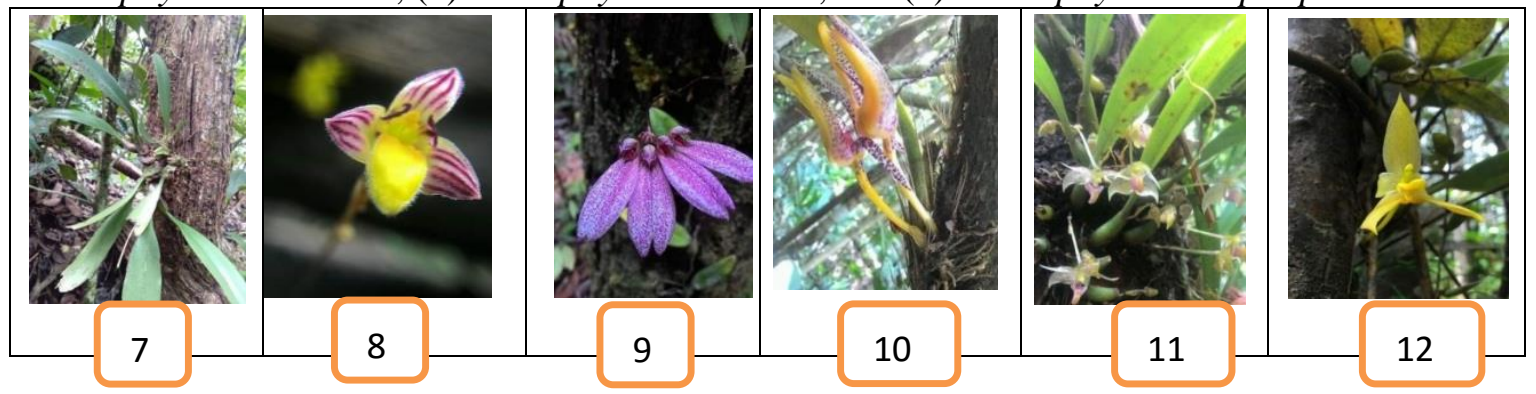

(7) Bulbophyllum gracillimum, (8) Bulbophyllum limbatum, (9) Bulbophyllum longiflorum,

(10) Bulbophyllum lyriforme, (11) Bulbophyllum otocilum, (12) Bulbophyllum pileatum 


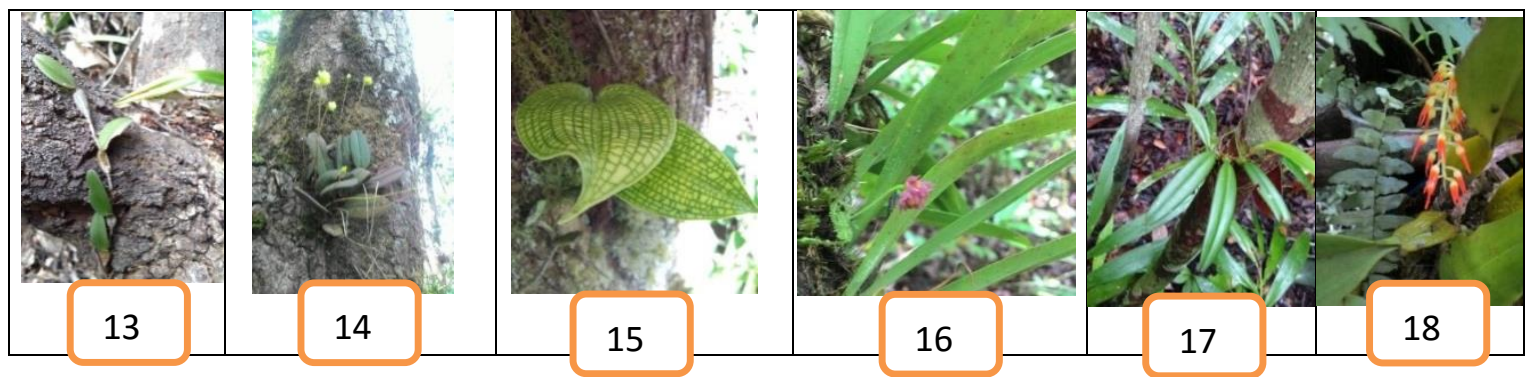

(13) Bulbophyllum planibulbe, (14) Bulbophyllum purpurascens, (15) Bulbophyllum reticulatum, (16) Bulbophyllum rubiferum, (17) Bulbophyllum sp. (18) Bulbophyllum triflorum

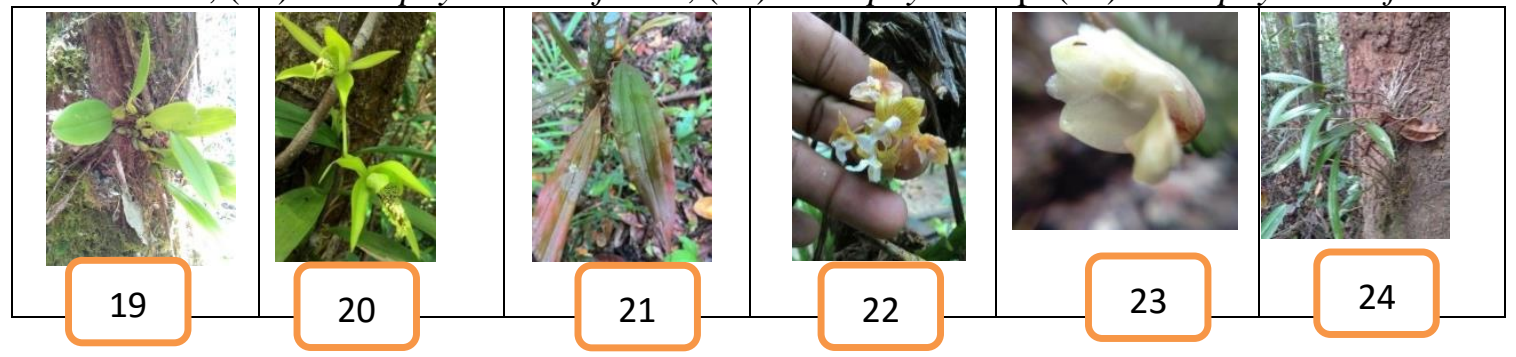

(19) Bulbophyllum vaginatum, (20) Ceologne peltastes, (21) Ceologyne sp. (22) Dendrobium cabro, (23) dendrobium leonis, (24) Dendrobium microglaphys.

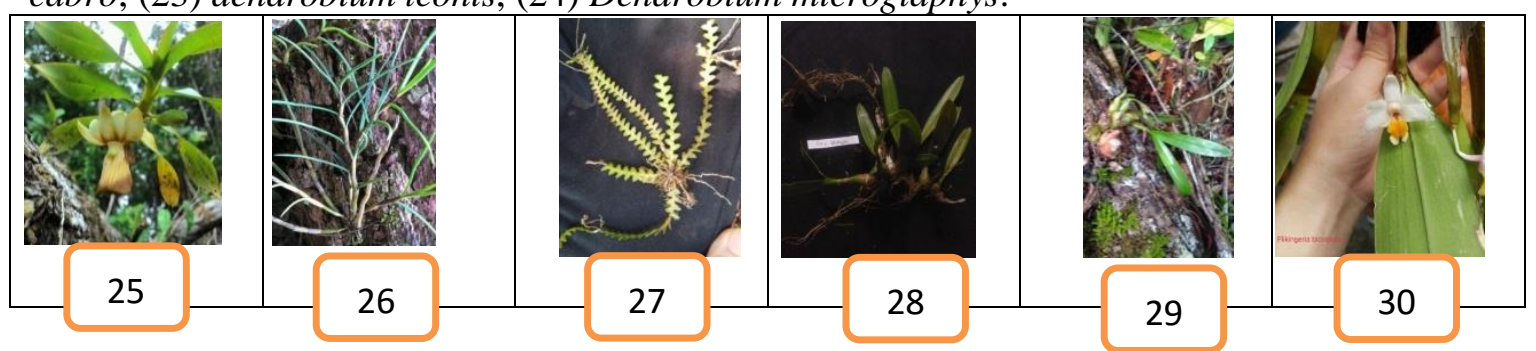

(25) Dendrobium kenepaiense, (26) Dendrobium pinifolium, (27) Dendrobium prostratum, (28) Eria leilophylla, (29) Eria sp., (30) Flickingeria bicostata

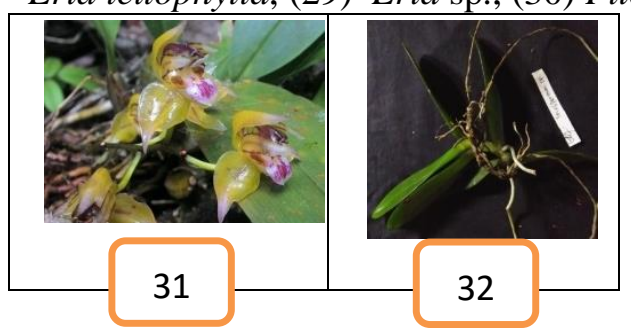

(31) Thecopus secunda, (32) Trixspermum sp.

\section{KESIMPULAN DAN SARAN}

Jenis-jenis anggrek yang ditemukan di hutan Desa Balai Sebut Kabupaten Sanggau pada ketiga tutupan tajuk hutan sebanyak 32 jenis dengan jumlah seluruh individu anggrek yang ditemukan adalah sebanyak 431 individu. Tutupan tajuk hutan tertutup ditemukan 16 jenis anggrek dengan jenis yang dominan adalah jenis Flikingeria bicostata. Tutupan tajuk hutan sedang ditemukan total 25 jenis anggrek dengan jenis yang paling dominan adalah Flikingeria bicostata. Tutupan tajuk hutan terbuka ditemukan 10 jenis anggrek 
dengan jenis yang paling dominan adalah Ceologyne peltastes.

Berdasarkan hasil pengamatan dilapangan ditemukan 9 jenis pohon inang yang menjadi tempat tumbuh anggrek. Hasil penelitian di kawasan hutan Desa Balai Sebut perlu dilakukan pelestarian dan perlindungan untuk mempertahankan jenis-jenis anggrek yang ada di habitatnya, supaya populasi anggrek tetap terjaga dan tidak terjadi penurunan keanekaragaman jenis khususnya oleh pemerintah dan instansi setempat.

DAFTAR PUSTAKA

Anwar JSJ, Damanik N, Hisyam dan Whitten AJ. 1994. Ekologi Ekosistem Sumatera. Yogyakarta: UGM.

Ewusie JY. 1990. Pengantar Ekologi Tropika. Institut Teknologi Bandung. Bandung.

Febriliani, Sri Ningsih M, Muslimin. 2013. Analisis Vegetasi Habitat Anggrek Di sekitar Danau Tambling Kawsan Taman Nasional Lore Lindu. Warta Rimba 1(1).

Firnando M, Rosa M, Harnani H. 2017. Identifikasi Famili Orchidaceae di kawasan Hutan Lindung Desa Sekendal Kecamatan Air Besar Kabupaten Landak. Hutan Lestari 5 (2): 183-191.

Frankie H. 2010. Orchids of Indonesia. Bekasi: Perhimpunan Anggrek Indonesia.

Kartohadiprodjo NS. 2009. Asiknya Memelihara Anggrek. Jakarta: Gramedia Pustaka Utama.

Komara A. 2008. Komposisi Jenis dan Struktur Tegakan Sorea balangeran (Koorth) Burck,
Hopea bancana (Boerl) Van Slooten dan Caumaraouna odorata Anbl di Hutan Penelitian Dramaga. Bogor Jawa Barat. Warta Rimba 5(2).

Mackinnon. 2000. Ekologi Kalimantan. Prenhallindo. Jakarta.

Odum EP. 1993. Dasar-dasar Ekologi. Terjemahan Tjahjono Samingan. Edisi Ketiga. Yogyakarta: Gajah Mada University Press.

Puspitaningtyas DM. 2010. Iventarisasi Anggrek dan Inangnya di Taman Nasional Meri Betiri Jawa Timur. Biodiversitas 8(3): 210-214.

Sarwono. 2002. Mengenal dan Membuat Anggrek Hibrida. Jakarta: Argo Media Pustaka.

Shannon CE, Wiener E. 1994. The Mathematical Theory of Comunication. Univercity llinois Press II., Urban Us.

Siregar C, Listiawati A, Purwaningsih. 2005. Inventarisasi Anggrek di Kabupaten Sintang, Kalimantan Barat. Biodiversitas 9(1): 21-24.

Sutiyoso Y, dan Sarwono B. 2005. Merawat Anggrek. Penebar Swadaya. Jakarta.

Sujalu AP dan Pulihasih AY. 2010. Keanekaragaman Epifit Berkayu Pada Hutan Bekas Tebangan di Hutan Penelitian Malinau (MrfCifor). Penelitian Hutan dan Konservasi Alam 8(3):211-216.

Tanjung RHR, Sufaati S, Runggaeari L. 2010. Analisa Vegetasi Jenis Pohon Pada Kawasan Hutan di Kampung Tablanusu Distrik Depapre Kabupaten Jayapura. Biologi Papua 2 (1): 23-31. 
JURNAL HUTAN LESTARI (2020)

Vol. 8 (1) : 180 - 192

Tirta IG, Laugrayasa IN, Irawati. 2010. Studi Anggrek Epifit pada Tiga Lokasi di Kabupaten Malinau, Kalimantan Timur. Buletin Kebun Raya 13 (1).

Yuanda. 2007. Studi Keanekaragaman dan Penyebaran Jenis Anggrek (Orchidaceae) di Kawasan Hutan Lindung Sagatani Singkawang. Protobiont 4(1): 170-177. 